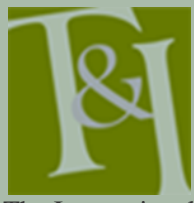

The International Journal for Translation \& Interpreting Research trans-int.org

\title{
Assessing periodization in histories of literary translation
}

\author{
Isis Herrero López \\ Independent Scholar \\ herreroisis@hotmail.com
}

DOI: 10.12807/ti.111202.2019.a05

\begin{abstract}
When investigating the history of translation of Jane Austen in Spain, I always feel the need to establish historical periods to handle materials, data and trends. From time to time, I also feel the need to redefine those periods, even to use different time frames altogether. However, it is only irregularly that I find academic debates about such an important part of research on translation history. In the present article, I examine the way in which we, Translation Studies scholars, reflect on periods and periodization systems. I build my analysis around three interlinked questions: the type of periods we use, how we use those periodization systems, and why we use those periods and not others. I examine theoretical reflections on translation history, and include practical case studies from four national histories of translation and/or literary translation (China, Finland, Turkey, and Spain). At the end, I emphasize that we, as a discipline and as individual researchers, must debate critically about our periods and periodization systems in order to advance in the study of history of translation with awareness and analytical perspective.
\end{abstract}

Keywords: history of translation, literary translation, periodization, historical periods, translation historiography

\section{Introduction}

When conducting historical research, a series of difficulties will hinder the labour of researchers and determine at least partially their interpretation of past events: the availability of documents and other sources, cultural and linguistic particularities, and periodization. The latter, an unsolvable issue and yet impossible to neglect (Postlewait, 1988, p. 318), has been largely passed over by researchers within Translation Studies. However, we cannot continue overlooking "the problems that arise in trying to carve up the past" (Le Goff, 2015 , p. x), for we always chunk the past into smaller, more manageable pieces for our studies and this has major repercussions for our interpretations. Historical research of any kind cannot escape periodization or the assumptions and arguments that come with it. In fact, we select periods according to our interests and our interpretations of sources and, in turn, our selection shapes the historical account we offer.

Because of this, researchers within Translation Studies must query what kind of periods we use and/or create, how we use them for studying the past and the present, and why they are relevant to us and our analyses. This historiographical concern, moreover, needs to be addressed in order to critically assess our performance as researchers. Are we imposing certain types of periodization on our materials? Can we use freely any periodization system available? Are our periods useful for and acceptable to our fellow researchers? Are our divisions and terminologies as unambiguous as we perceive them to be?

So far, within Translation Studies, there have been but few efforts to answer these questions or even to define the different phases that compose 
translation history. The discussion was addressed in depth for the first time by Foz in 2006, but it seems not to have advanced much since. At the time, Foz commented on the subjective and artificial nature of periods, and on how many periodization systems involve a certain essentialism and a sense of totality. Moreover, Foz presented several proposals for periodizing translation history and argued that they all used preconstructed divisions with an evolutionary outline and a defined, purpose-driven end. In fact, the periodization proposals she reviewed were fundamentally constructed to affirm that the latest stage of translation history - that is, the present day - is the culmination of a long-term development toward better practice and, in some cases, toward deep and complex theorization.

In this paper, I will examine the usage of periodization in Translation Studies, focusing on the three main questions alluded to above - that is, the 'which', 'how' and 'why' of period selection. These questions are deeply intertwined and form the basis for my analysis; thus, I address them side by side. In order to approach the issue of periodization in an efficient and manageable way, I concentrate on translation practice, particularly that of literature, due to the extensive examples of historical research on literary translation. I examine theoretical reflections on translation history, practical case studies and four national histories of translation and/or literary translation, as well as my own periodization system for the history of translation of Jane Austen in Spain.

\section{Previous discussion on periodization in Translation Studies}

When doing historical research in Translation Studies, it is quite common to assume as valid some available system of periodization without questioning its adequacy to our object of study or its implications. Although historians have been arguing about such issues for the past century, forcing themselves "to make explicit their choices about chronology and periodization" (Introduction Ch.5, 2016, p. 289), within Translation Studies we are yet to go deep into this discussion. Although in 2001 López Alcalá stated that there are two separated practices in Translation Studies - either to follow traditional periods (i.e. Middle Ages, Renaissance, etc.) or to construct independent periodizations (pp. 117188) -, these reflections have been rather individualistic and scattered before Foz's, and largely even afterwards. However, as a discipline we must explore "how the concept of periodization acts as a controlling generalization, an unconscious or unarticulated presupposition" (Postlewait, 1988, p. 317). The first step is to discuss the fact that most researchers mention periodization as a concern to be considered in historical research, but do not explore this issue in all its extent.

Already in their early approaches to the methodological concerns of translation history, D'hulst (1995) and Pym (1998) treated the question of periodization superficially. D'hulst (1995) highlighted the complexity of the time factor for the historian (p. 23) and how this concern only manifests itself indirectly through the periodization used for each given corpus (p. 24). He did not delve into the complex nature of periods and periodization systems, though. He brought, instead, the focus onto Braudel's distinction of longue durée, moyenne durée, and courte durée (pp. 24-25), which deals with the temporal scale of a historian's approach rather than with dividing time in periods. Pym (1998), for his part, briefly referred to periods in his reflections about the diachronic representation of frequencies (p. 74). He focused on the distribution of data according to short time intervals and made no comments on the broader question of how periods may affect our case studies from the start.

D'hulst addressed the issue of periodization again in 2010 and indicated how metahistoriography is concerned with the problems that different 
conceptualizations of time may give rise to (p. 398). His deliberations (p. 402) alluded to the specific concerns I am dealing with in this paper - which temporal divisions to use, whether to borrow them from other disciplines, the combination of different time partitions -, but his focus returned again to Braudel's three-level temporal scale. He asserted that this scale "could help to escape periodizations simply borrowed from the history of literature or from the history of ideas (like literary movements, geopolitical events, etc.)" (pp. 402403), although he did not offer any concrete advice. Likewise, O'Sullivan (2012), in her introduction to the special issue of Translation Studies on translation history, mentioned but did not explore the issue of periodization ( $\mathrm{p}$. 132).

As remarked earlier, Foz's discussion on periodization (2006), in fact, has offered the strongest argument in favour of larger debates and assessments of our usage of periods, but her call has encountered little success so far. Pérez Blázquez (2013, p. 10trans), for instance, remarked how the wide interest in translation history in Spain has not implied the production of "established periods of translation history". In fact, he asserted that Lafarga and Pegenaute's work (2004a), on which I will comment later in detail, failed to do so because it used literary and cultural history as chronological guides (p. 9trans). Pérez Blázquez, in addition, considered that establishing Spain's own periods for translation history "would make a pivotal contribution to the methodological soundness of historical research and the theoretical reflection on translation" ( $p$. 9 trans). Once again, he did not contribute a deeper reflection on the consequences of using borrowed periods or suggest how to construct translation-based periods. Similarly, Vega and Pulido (2013, p. 58) regarded the usage of literary periods as unsuitable when aspiring "to consider translation as an activity that responds to specific economic and social conditions, regardless of preconceived classifications". On this occasion, they offered specific and interdisciplinary criteria for developing a periodization distinct to Translation Studies (pp. 58-59). Their proposal, however, simply appropriated periods from other disciplines uncritically, as it proposed the combination of "large and imprecise period demarcations of general history" with as many sub-divisions of "thematic "units"” as possible (p. 58).

More recent contributions to the question of periodization have continued this trend of superficial and imprecise reflections. D'hulst (2015) kept insisting on Braudel's three-level temporal scale and highlighted the identification of "les différentes temporalités de la traduction et les interactions entre celles-ci" (p. 294) as one of the eight challenges for the transmission of historical knowledge within Translation Studies. Once more, he went no deeper into periodization. Rundle's (2018) contribution to the debate also remained within the recurrent limits of the discussion. He highlighted that translation history "involves both choosing a timescale that is defined on the basis of our sources, and establishing periods that become frames against which we interpret those sources" (p. 243), but did not go further in his considerations.

\section{Periodization in four national histories of translation}

This lack of metahistoriographical reflection is, unfortunately, widely spread also in our case studies. This is well illustrated by my analysis of four national histories of translation and/or literary translation. The comparative examination of the histories of China (Lin, 2002), Finland (Riikonen, Kovala, Kujamäki \& Paloposki, 2007), Turkey (Parker, Tahir Gürçağlar \& Milton, 2015), and Spain (Lafarga \& Pegenaute, 2004a) shows how Translation Studies scholars have not even reflected yet on which kind of periodization systems they use. In fact, these histories display a great diversity of periodization systems as well as the difficulties of adopting periods based on political and/or cultural history to 
translation history. The histories of Spain and Finland, due to their extensive lengths and detailed chapters on specific periods, also reveal the complexity of choosing a single periodization system that matches translation flows and fluctuations.

In their introductory outline of Turkey's translation history, Parker et al. (2015, pp. 3-8) used a periodization system based on the political history of Turkey. In fact, the two main periods used to frame the narrative are the Ottoman Empire and the Republic of Turkey, with 1923 as the border between the two. Several historical milestones were brought up to indicate linguistic and cultural changes within these larger periods (i.e. the dominance of Turkish language by $16^{\text {th }}$ century or the Alphabet Reform of 1928) as well as government decisions affecting the practice of translation, such as the institutional translations of the Tulip Period (1718-1730) and those of the Tanzimat period (1856-1876). The division between the Ottoman Empire and the Republican period was further used for organizing the articles in chapters. Interestingly, on this occasion an overlapping period based on culture "transition" - was used to offset the sense of rupture that could be implied by the political shift from empire to republic. In addition, this period inadvertently turned Turkey's translation history into a progressive continuity.

This option of bridging two apparently opposed periods through an overlapping period contrasts with the intermittent periodization system selected by Lin (2002) for his translation history of China. Lin, in fact, only indicated five major periods -or waves, as he called them- of translation on the basis of the kind of texts being translated into Chinese: the Buddhist texts period (1481037), the Western scientific and technological texts period at the end of the Ming dynasty (1368-1644), the Western humanities and social science texts period at the end of the Qing dynasty (1644-1911), the Russian and socialist texts period (the 1950s), and the mass translation period (starting in 1970s). Lin's decision to highlight only these periods was not just based on his view of historical causality (on which I will comment later), but also on translation criteria, unlike the political periodization of Parker et al. In addition, Lin's periodization system provides an interesting reflection on the nature of history: Lin presented history as a discontinuous sequence of turning points and asymmetrical phases instead of as a chain of interconnected events.

A third way of periodizing translation history is found in Lafarga and Pegenaute's Historia de la traducción en España (2004a). The periods selected by the editors originated mainly in the discipline of literature, although the authors of the different sections frequently linked these periods to political phases and events. This is, for example, the case of the Romantic period: the death of Ferdinand VII in 1833 and the end of absolutism in Spain was considered the start of the period (Pegenaute, 2004, p. 321), whereas the publication of the first realistic novel in 1849 was equated to the start of its decline (p. 323). However, at the end of the book, politics took over and two of the last sections related to Spanish language were organised around the Spanish Civil War (1936-1939) and its political and cultural consequences - that is, the establishment of the Francoist Dictatorship and its all-encompassing control.

These periods of Spain's history of literary translation appeared in chronological order, though with some uncommented overlaps and gaps in the table of contents. The editors must have done so intentionally, presumably to link more easily the translation flows to "las poéticas vigentes o generalmente aceptadas en cada período" "the poetics in force or generally accepted in each period”, Lafarga \& Pegenaute, 2004b, p. 16). ${ }^{1}$ Their unquestioning usage of these pre-configured literary periods, however, conflicted with periodizing the sections on Basque, Catalonian and Galician languages, where discrepancies, gaps and political (sub)divisions appeared. In the Galician section, for instance,

\footnotetext{
${ }^{1}$ All translations into English are mine.
} 
the regional Rexurdimento [resurgence] (1888), the Galician Nationalist movement (1917-1936) and the Francoist period (1936-1975) are given central relevance.

The blending of multiple layers of periodization, as the examples above show, is a very common strategy for translation historians. After all, translation activities do not happen in a vacuum, either cultural or socio-political. We cannot simply erase the interconnections existing between the translators' activities and their changing contexts, even if we aim at writing a translation history with periods based on translation criteria, "independently of big numbers and national political regimes" (Pym, 1992, p. 226). Using a compound system of periods is, however, as risky as transferring whole periodization systems from other disciplines without considering the implications of such a decision. After all, combining periodization systems involves assembling potentially diverging visions of history, with their assumptions about the unity of each period, the reasons behind partitions, and their individual narrative frameworks converging into a single entity.

Because of this, I consider the history of literary translation into Finnish compiled by Riikonen et al. (2007) to be a noteworthy presentation of an effectual periodization system. Riikonen et al. (2007) established, first, a large framework following the political periods of Finnish history -the Swedish rule era (ca. 1250-1809), the Era of Autonomy as Russia's Grand Duchy (18091917), and the Era of Independence (from 1917). Within this political structure, which, of course, had significant repercussions on Finnish language and culture, the editors and authors adopted different methods of diving time: sometimes they were guided by cultural issues -i.e. literary genres, source languages, or international and national cultural movements-, in others by political circumstances - such as the Interwar Period-, and in yet others by a combination of both -for instance, the Era of Stabilization (roughly late 1800s-early 1900s). In addition, when the materials demanded it, the larger framework of political periods got broken and readjusted to attend the complexities of translation activities. This is the case of the section on the translation of classics, which covers a time period extending throughout the 1800s and into the 1930s.

Riikonen et al. (2007) reflected briefly about periodization issues. In fact, it is clearly stated that the compilation "ei pyri olemaan kauttaaltaan kronologisesti etenevä 'suuri kertomus' suomennosten vaiheista" ("does not aim at being in every respect a chronologically progressing 'great narrative' about the history of Finnish translations", Kovala, Kujamäki, Paloposki \& Riikonen, 2007, p. 10). The most interesting characteristic of the periodization system used in this translation history has to do with it malleability. The capacity of the periods to be reorganized and remodelled according to the materials under study makes it a helpful tool for researchers, facilitating the expansion of our scope of research rather than limiting it. Nevertheless, as I will comment in the following section, such a shifting system for periodization may produce problems when aiming at discipline-wide considerations about methodology and discussions on translation historiography.

\section{Constructing periods, analysing their effects}

On the basis of the comparative analysis above, we can affirm that researchers almost always take periodization for granted (see Postlewait, 1988, p. 306). In fact, the translation histories of Turkey, China and Spain incorporated preexisting time divisions without considering even briefly the consequences of using these periodization systems, unlike Riikonen et al. (2007). When Parker et al. (2015), Lin (2002), and Lafarga and Pegenaute (2004a) decided to incorporate periods from other disciplines uncritically, they endorsed the validity of those systems, their suitability and their underlying 
conceptualizations of history. The discussion should not be, however, about whether to borrow other disciplines' periods or to construct our own, for this focus may result in a reductionist perspective in view of the multiple interests of the Translation Studies discipline. Rather, the discussion must focus on the repercussions that periodization systems, whether borrowed or constructed, have on our conception both of translation history and of the discipline of Translation Studies.

A simple reflection on this issue can be made through the examples offered by Rundle (2018, p. 244) to illustrate how the political division of the Francoist Dictatorship (1936-1975) in Spain has become the framework against which researchers interpret their materials. Rioja Berrocal (2010) used for her research the time frame of Manuel Fraga's term as Minister of Information and Tourism between 1962 and 1969, whereas Gómez Castro (2008) adopted the new censorship law of 1966 as the starting point for her study of the Francoist censorship's last years. This overlap between their periodization systems highlights two relevant issues: (1) period systems are not universal, not even among the members of a research group; (2) our periodization choices determine the kind of historical accounts we offer. Rioja Berrocal's account focused on the influence of Fraga's term on the censorship evaluations, drawing a connection between a single politically powerful individual and the translation performance of the period 1962-1969. The period selection of Gómez Castro, on the other hand, presented the changes in the translation agents' strategies as the result of a legislative action, downplaying their agency in further developing the strategies adopted during the first thirty years of the Dictatorship.

This small comparison shows how our research, as Belle (2014, p. 45) remarked, "suffers at times from a lack of critical attention to the construction of translation discourses through history". Our study of translation from a historical perspective requires us to reflect actively on periodization and its implications, on how we organize history, but, more importantly, on how we construct history as a narrative. This notion, originally developed by Hayden White (1978), emphasizes the fact that, under each historical account, there is a specific interpretation of the past, one constructed by actively plotting diverse events together into sequences (p. 58). Belle's research (2014), for instance, showed that there is a general tendency to adopt a narrative of linear progress in which history is a succession of improvements towards what is considered in the discipline as the best translation paradigm, strategic approach, or sociocultural stance. She also highlighted the importance of remembering that in any given moment there are "several modes of translation discourse developing" at the same time and, in the case of literary translation, alongside "writings on literary theory and criticism" (p. 59). A linear progress approach can conceal these simultaneities and intertwining as well as their relevance for our understanding of historical happenings, thereby producing the false image of a unified and coherent sequence of events and, thus, of history (Rundle, 2018, p. 236).

We must remain aware that periods are a human invention that, even when agreed upon by scholars, never correspond to an objective reality (Le Goff, 2015, p. 113-114). However, the fact that we aim at presenting historical realities through our period-organized narratives must make us inquire about the accounts we are producing. Are we presenting history as a succession of revolutionary transformations? Or do we see history as an evolution-driven whole with a clear final aim? Are periods hermetic compartments that succeed each other or instead permeable strata that partially overlap but to dissimilar extents? Each of these options, as well as any other possible perspectives, will imply a different attitude not only towards periodization and our period selections, but also towards what our research can contribute to the greater and more comprehensive analysis of translation history. 
Periods are not only tools; they contain at least implicit arguments. The apparently simple selection of denominations for our periods already comprehends a vision of history and its divisions, for "all period concepts carry connotative, not just denotative, meanings" (Postlewait, 1988, p. 318). For instance, Lin's usage of "waves" (2002) creates a history filled with sudden, massive cultural shifts, whereas Riikonen et al.'s (2007) division into "eras" presents a more gradual, long-term change. Thus, it is not enough to justify our periods by their convenience and utility: we need to discuss the interpretative nature of these useful tools and to evaluate their capacity for managing and generating meaning. By selecting specific time divisions and assigning them this or the other denomination, we are constructing a distinctive interpretation of history and, consequently, argumentative narratives "based upon ideas of affinity and diversity, norm and variation, continuity and disjunction" (Postlewait, 1988, p. 300).

In the four national histories of (literary) translation observed above, periods were, to a great extent, taken for granted and the researchers' interest in the selected period(s) justified the usage of those specific periodization systems. On very few occasions did the researchers seem conscious of the historical narrative they offered or the arguments that these periods might bring up. In each of these four cases an underlying vision of history got highlighted in the discourse, projecting personal and communal beliefs about the past and the present. In addition, woven in their implicit narratives, we can meet with different perceptions of translation and its relevance in national histories.

In Parker et al.'s introduction (2015) to the history of translation in Turkey, their comments repeatedly emphasized the turning point symbolised by the establishment of the Turkish Republic. By connecting this political transformation with "the Westernization movement, hence modernization" (p. 1) in the country, Parker et al. connoted a narrative of disruption and progress, of radical change hinging on the 1923 "break with the Ottoman past" (p. 1). This rhetoric of disruption surfaced mainly in two elements of the book: in the distribution of the articles in sections, and in lexical choices in both the introduction and the preface. The three sections of the book -"Section I. Ottoman conceptions and practices of translation", "Section II. Transition and transformation", and "Section III. The republican revolutionary turn: Ideology and politics"- seemed to present a chronological order. However, the second section was mostly inscribed within the temporal limits of the Republican period, with brief references to the Ottoman Empire in order to present the evolution of translation practices. In relation to this group of articles, the editors themselves used profusely the word "transformation" and derivates (p. 16), as well as references to "remarkable advances", "a major cultural breakthrough" and "contemporary developments" (p. 16). These semantic choices implied a certain sense of progress happening hand-in-hand with more or less radical alterations and leading to present-day "dynamics of change" (Tahir Gürçağlar, Parker \& Milton, 2015, p. viii), thus presenting translation as a powerful cultural agent.

The historical account of China by Lin (2002) offered a clearer insight into his vision of history. Although he does not actively reflect on his interpretation of historical events, he stated that each period was the consequence of "the needs and demands of society" (p. 172). Thus, translation during the Buddhist period "can be seen as to satisfy spiritual needs" (p.172), in the same way that "During the last days of the Qing dynasty, the need to learn from foreign countries was widely felt and recognized" (p. 175), leading to a period focused on the translation of Western humanities and social science texts. Lin's narrative is that of functional causality: periods and history are defined by particular needs that are believed to produce certain kinds of translation practices as a response to those needs. According to this narrative, translation is just a reaction: the agency of individual translators is downplayed and 
translation does not have a life of its own until "a cultural vacuum appears" ( $p$. 175).

In the case of Lafarga and Pegenaute (2004a and 2004b), the image we receive of translation is that of a discipline and profession directly dependent upon literary movements. With their selected periodization system, Lafarga and Pegenaute confined translation and literary translation in particular to a subsidiary role in relation to the production of literature, to the point that translation activities got limited temporally to international and national variations in the literary panorama. Because of this, we must look for Lafarga and Pegenaute's underlying vision of history in theoretical reflections on literary periods and their accompanying narratives. According to Underwood (2013), the periodization system used in Literary Studies has been constructed on a vision of history as discontinuity and contrast: in fact, periods are defined by "vividly particularizing and differentiating vanished eras, contrasting them implicitly to the present as well as against each other" (p. 3). Presenting translation history through such a series of discontinuous and contrasting fragments, in turn, implies cycles of translation practice in which each period is characterized by counteracting the previous tendencies.

A completely different narrative emerged from Riikonen et al.'s compilation (2007). Their multi-level periodization, commented in the previous section, established a complex vision of history based on the interdependence of politics and culture. Neither the different sections of the compilation nor the preface (Kovala et al., 2007) focused exclusively on any individual factor: rather they tried to tie together multiple factors such as ideology, economics, politics, and language policies (p. 9), showing the heterogeneity of the whole history as well as individual periods. This narrative, in addition, did not attempt to be exhaustive or definitive (p. 9) to the point that traditional time divisions were not assumed to provide a single way of organizing the material. Other criteria - for instance, genres - were used for approaching history from a culturally oriented perspective (p. 10), thus offering an image of translation as an essential part of Finnish cultural development. In particular, it was emphasized how "suomennosten merkitys on sekä kotimaisen kirjallisuuden kehityksessä että kirjallisuusvaikutteiden leviämisessä ollut kiistaton" ("the significance of Finnish translations in both the development of domestic literature and the diffusion of literary influences has been undeniable", p. 9).

The fact that Kovala et al.'s preface offered concise yet explicit considerations about the intention behind their writing of history of literary translation into Finnish is thought-provoking evidence of our need for reflection of this kind within Translation Studies. The editors of this compilation, at least, were aware that the writing of history involves selecting a vision of history which, in turn, implies a specific narrative and specific tools. Periods, as any other research tool, carry explicit and implicit arguments. Avoiding dealing with this issue will only aggravate its effects, for we will continue to take for granted the neutrality of our periodization systems when they are not actually neutral. Since periodization is an integral part of historical research, we must begin to reflect actively on them and state openly their narrative implications

\section{Periodizing the history of translation of Jane Austen in Spain}

In order to exemplify the necessity of reflecting actively on our historiographical decisions, I present here a critical review of my own periodization for the history of translation of Jane Austen in Spain (Herrero López, 2016 \& 2017). For my analysis of the 100-year history of translations of Jane Austen into Spanish, I originally proceeded from the time divisions established around the Francoist Dictatorship (1936-1975). Since my analysis focused on the effect of the Francoist censorship on the translations of Austen's novels, such a starting 
point seemed reasonable, although at the time I never reflected on its sociopolitical and cultural implications. Through this choice, I established a dichotomy of older conservative translations versus modern, more liberal translations after the Dictatorship, following the retranslation hypothesis. With this dichotomy in mind, I also linked politics and culture so tightly that it left little agency to publishers and translators during the Francoist years. Later analyses, however, contradicted my dichotomous construct and highlighted the importance of individual and communal agencies.

In these later analyses, I gave a more central role to the flows of translation and publication of Austen's novels. Thus, I started by compiling a chronological diagram of the political and cultural events and phenomena in Spain alongside the publication statistics and data of all editions of Austen's translated works. This allowed me to confirm the utility of existing periods - such as the First Francoism (1936-1959) and the Second Francoism (1960-1975) - as well as to create case-specific periods - for instance, the bicentenaries' period (20112019). Following the flows of the literary market has helped me not only to identify multiple reasons for Austen's popularity in Spain in given time periods, but also to link the translation flows to economic, socio-political and cultural trends. In this way, the division between First and Second Francoism has proven more relevant for my study of Austen's history of translation in Spain than, for example, the division created by the 1966 new censorship law, used by Gómez Castro (2008) in her study of the Francoist censorship's last years. Similarly, focusing on the peaks of publication has highlighted the agency of publishers and translators, bringing into the foreground the individuals involved in such history of translation.

\section{Conclusion}

Throughout this brief revision of the theoretical reflections of Translation Studies scholars on translation history and of their case studies, I have emphasized the necessity of the discipline to start talking critically and intensely about periodization. It is important that we, both as discipline and as individual researchers, reflect more frequently on the temporal divisions we use in our research due to their centrality in our projects. After all, it is very difficult to carry out research on history without using periods and periodization systems.

In addition, we must reflect on and discuss specific issues about our usage and naming of periods. The 'which', the 'how' and the 'why' behind our temporalization choices have to be explicitly justified, argued, and debated, even contested at times by fellow researchers and by ourselves. We need to develop awareness first, and immediately after that, the habit of analytically reporting our periodization choices in relation to our research topics and our interpretations. More specifically, we need to attend to the hermeneutic circle that takes place every time we design and carry out our historical research projects.

Debates about the 'which' will easily focus on whether we should borrow periodization systems from other disciplines or create periods based on translation-related criteria (i.e. flows between countries/languages, practical strategies, theoretical approaches). The debate will extend in both directions, of course. When considering borrowing, discussion will surely develop around the multiple interdisciplinary connections of Translation Studies and how the timelines used in those other disciplines can be imported into our research projects. Moreover, we will have to consider whether these loaned periods are sound enough as they are, or if they require adaptation and to what extent. Considerations about the possibility of producing one or many periodization systems for our own discipline will, conversely, unfold in connection with the possible criteria to use and the practicality of those criteria. 
The question of 'how' must be answered promptly, and with words such as deliberately, explicitly, and critically. With this as our maxim we may begin reflecting on how our periodization choices shape our projects and interpretations. We will, thus, reconsider how our selection of periods is mostly based on various specific interests and pre-assumptions, and query if there are alternative periodization systems to the one we have used so far. Moreover, we will go deeper into asking how we deal with the consequences and repercussions of our periodization choices. We will debate possible ways of controlling the effect that periods, as frameworks of interpretation, have on our planning of research and on our analysis of materials, as well as the partial and/or false images that our periods produce of history and of the practice of translation itself.

In relation to the 'why', our reflections must go beyond defining the obvious reasons for the usage of periods: because we believe that we need them and because our historical interests make us use them. Of course, it is important to ponder why we periodize at all, but right now Translation Studies scholars must start with more tangible questions as a first step in our metahistoriographical awakening. We must interrogate the underlying narratives that we construct through our periodization choices. It is important, firstly, to become conscious of the possible stories we and other scholars are integrating into our projects, wittingly or unwittingly, and, secondly, to develop a critical eye for detecting the interpretative consequences of those underlying stories. We will, certainly, reconsider our choices and examine the possibility of telling multiple narratives with a single periodization system. In the same way, we will also test the diversity of the stories produced when different periodization systems are applied to the same set of materials.

Last but not least, we need to become aware that these three questions do not only apply to the production of grand narratives. In fact, they are equally relevant when we work on small-scale studies as the above example about the Francoist censorship demonstrates. The call for reflection that I am making to our discipline in this article comes from my own re-evaluations of my research on the history of the translations of Austen in Spain. In considering a 100-year history, the periods I use do not necessarily have established names or wide acceptance among scholars. They are based on the political changes of Spain, on the specific translation flows of this author, on the rises and falls of the Spanish literary market, and on the desire to assess if the retranslation hypothesis applies to my case study. Are they right? Are they wrong? Can I use periods differently?

In order to answer these questions, a general broadening of scope is called for, and accordingly I invite fellow scholars to begin questioning the usage of periods in the discipline of Translation Studies.

\section{References}

Bastin, G. L. (2006). Subjectivity and rigour in translation history: The case of Latin America. In G. L. Bastin \& P. F. Bandia (Eds.), Charting the future of translation history (pp. 111-129). Ottawa: University of Ottawa Press. Retrieved from https://books.openedition.org/uop/320

Belle, M. A. (2014). At the interface between translation history and literary history: a genealogy of the theme of 'progress' in seventeenth-century English translation history and criticism. The Translator, 20(1), 44-63.

D'hulst, L. (1995). Pour une historiographie des theories de la traduction: questions de méthode [For a historiography of translation theories: questions of method]. TTR: traduction, terminologie, rédaction, 8(1), 13-33. Retrieved from https://www. erudit.org/en/journals/ttr/1995-v8-n1-ttr1482/037195ar/ 
D’hulst, L. (2010). Translation history. In Y. Gambier \& L. van Doorslaer (Eds.), Handbook of Translation Studies (Vol.1, pp. 397-405). Amsterdam/Philadelphia: John Benjamins.

D'hulst, L. (2015). Quels défis pour l'histoire de la traducion et de la traductologie? [Which challenges for the history of translation and of translatology?]. Meta, 60(2), 281-298. Retrieved from https://www.erudit.org/en/journals/meta/ 2015-v60-n2-meta02055/1032858ar/

Foz, C. (2006). Translation, history and the translation scholar. In G. L Bastin \& P. F. Bandia (Eds.), Charting the future of translation history (pp. 131-144). Ottawa: University of Ottawa Press. Retrieved from https://books.openedition.org/uop/321

Gómez Castro, C. (2008). Translation and censorship in Franco's Spain: Negotiation as a pathway for authorization. In C. O'Sullivan (Ed.), Translation and negotiation: Proceedings of the seventh annual Portsmouth translation conference (pp. 63 76). Portsmouth: University of Portsmouth. Retrieved from http://www2.port.ac. uk/media/contacts-and-departments/slas/events/tr07castro.pdf

Herrero López, I. (2016). Jane Austen through Francoist customs: what censorship file can tell about the publishing world of the First Francoism (1936-1959). Parallèles, 28(2), 62-75. Retrieved from https://www.paralleles.unige.ch/files/ 5715/2839/0413/Paralleles_28-2_2016_herrero-lopez.pdf

Herrero López, I. (2017). A historical reflection on Jane Austen's popularity in Spain. The ESSE Messenger, 26(2), 27-39. Retrieved from http://essenglish.org/ messenger/wp-content/uploads/sites/2/2017/12/26-2-W2017.pdf

Introduction (Ch. 5). (2016). In R. E. Dunn, L. J. Mitchell \& K. Ward (Eds.), The new world history: A field guide for teachers and researchers (pp. 289-296). Oakland: University of California Press.

Kovala, U., Kujamäki, P., Paloposki, O., \& Riikonen, H. K. (2007). Esipuhe. In H. K. Riikonen, U. Kovala, P. Kujamäki \& O. Paloposki (Eds.), Suomennoskirjallisuuden historia (Vol. 1, pp. 9-11). Jyväskylä: Gummerus Kirjapaino Oy.

Lafarga, F., \& Pegenaute, L. (Eds.) (2004a). Historia de la traducción en España. Salamanca: Editorial Ambos Mundos.

Lafarga, F., \& Pegenaute, L. (2004b). Introduction. In F. Lafarga \& L. Pegenaute (Eds.), Historia de la traducción en España (pp. 11-18). Salamanca: Editorial Ambos Mundos.

Le Goff, J. (2015). Must we divide history into periods? (M. DeBevoise, Trans.). New York: Columbia University Press. (Original work published in 2014).

Lin K. (2002). Translation as a catalyst for social change in China. In M. Tymoczko \& E. Gentzler (Eds.), Translation and power (pp. 160-183). Amherst and Boston: University of Massachusetts Press.

López Alcalá, S. (2001). La historia, la traducción y el control del pasado. Madrid: Universidad Pontificia Comillas.

O'Sullivan, C. (2012). Introduction: Rethinking methods in translation history. Translation Studies 5(2), 131-138. Retrieved from https://www.tandfonline.com/ doi/full/10.1080/14781700.2012.663594?scroll=top\&needAccess=true

Parker, S., Tahir Gürçağlar, Ş., \& Milton, J. (2015). Introduction. In Ş. Tahir Gürçağlar, S. Parker \& J. Milton (Eds.), Tradition, tension and translation in Turkey (pp. 124). Amsterdam and Philadelphia: John Benjamins.

Pegenaute, L. (2004). La época romántica. In F. Lafarga \& L. Pegenaute (Eds.), Historia de la traducción en España (pp. 321-396). Salamanca: Editorial Ambos Mundos.

Pérez Blázquez, D. (2013). Critical review of the bibliography on the History of Translation in Spain. (S. Herrero Díaz, Trans.) MonTI 5, 1trans-13trans. Retrieved from https://rua.ua.es/dspace/bitstream/10045/35006/1/MonTI_05_05_eng.pdf

Postlewait, T. (1988). The criteria for periodization in theatre history. Theatre Journal, 40(2), 299-318.

Pym, A. (1992). Shortcoming in the historiography of translation. Babel, 38(4), 221235. Retrieved from http://usuaris.tinet.cat/apym/on-line/research_methods/1992 history.pdf

Pym, A. (1998). Methods in translation history. Manchester: St. Jerome Publishing.

Riikonen, H. K., Kovala, U., Kujamäki, P., \& Paloposki, O. (2007). Suomennoskirjallisuuden historia (Vols. 1-2). Jyväskylä: Gummerus Kirjapaino Oy. 
Rioja Berrocal, M. (2010). English-Spanish translations and censorship in Spain 1962-1969. inTRAlinea 12. Retrieved from http://www.intralinea.org/archive/ article/English-Spanish_Translations_and_Censorship_in_Spain_1962-1969

Rundle, C. (2018) Temporality. In L. D’hulst \& Y. Gambier (Eds.), A history of modern translation knowledge: Sources, concepts, effects (pp. 235-246). Amsterdam: Benjamins.

Tahir Gürçağlar, Ş., Parker, S., \& Milton, J. (2015). Preface. In Ş. Tahir Gürçağlar, S. Parker \& J. Milton (Eds.), Tradition, tension and translation in Turkey (pp. viiix). Amsterdam and Philadelphia: John Benjamins.

Underwood, T. (2013). Why literary periods mattered: Historical contrast and the prestige of English Studies. Standford: Stanford University Press.

Vega, M., \& Pulido, M. (2013). The history of translation and of the theory of translation in the context of Translation Studies. MonTI, 5, 39-70. Retrieved from https://rua.ua.es/dspace/bitstream/10045/35000/1/MonTI_05_02.pdf

White, H. (1978). Tropics of discourse: Essays in cultural criticism. Baltimore/London: The John Hopkins University Press. 